\title{
Bacteria encapsulated electrospun nanofibrous webs for remediation of methylene blue dye in water
}

\author{
Omer Faruk Sarioglu ${ }^{\mathrm{a}, \mathrm{b}}$, Nalan Oya San Keskin ${ }^{\mathrm{b}, \mathrm{c}, \mathrm{d}}$, Asli Celebioglu ${ }^{\mathrm{a}, \mathrm{b}}$, \\ Turgay Tekinay ${ }^{\mathrm{d}, \mathrm{e}, * *}$, Tamer Uyar $^{\mathrm{a}, \mathrm{b}, *}$ \\ a Institute of Materials Science E Nanotechnology, Bilkent University, 06800, Bilkent, Ankara, Turkey \\ b UNAM-National Nanotechnology Research Center, Bilkent University, 06800, Bilkent, Ankara, Turkey \\ c Polath Science and Literature Faculty, Biology Department, Gazi University, 06900, Polatl, Ankara, Turkey \\ d Life Sciences Application and Research Center, Gazi University, 06830, Golbasi, Ankara, Turkey \\ e Department of Medical Biology and Genetics, Faculty of Medicine, Gazi University, 06500, Besevler, Ankara, Turkey
}

\section{A R T I C L E I N F O}

\section{Article history:}

Received 31 August 2016

Received in revised form

22 December 2016

Accepted 18 January 2017

Available online 19 January 2017

\section{Keywords:}

Bacteria

Bioremediation

Electrospinning

Encapsulation

Methylene blue

Nanofibers

\begin{abstract}
A B S T R A C T
In this study, preparation and application of novel biocomposite materials that were produced by encapsulation of bacterial cells within electrospun nanofibrous webs are described. A commercial strain of Pseudomonas aeruginosa which has methylene blue (MB) dye remediation capability was selected for encapsulation, and polyvinyl alcohol (PVA) and polyethylene oxide (PEO) were selected as the polymer matrices for the electrospinning of bacteria encapsulated nanofibrous webs. Encapsulation of bacterial cells was monitored by scanning electron microscopy (SEM) and fluorescence microscopy, and the viability of encapsulated bacteria was checked by live/dead staining and viable cell counting assay. Both bacteria/PVA and bacteria/PEO webs have shown a great potential for remediation of MB, yet bacteria/PEO web has shown higher removal performances than bacteria/PVA web, which was probably due to the differences in the initial viable bacterial cells for those two samples. The bacteria encapsulated electrospun nanofibrous webs were stored at $4{ }^{\circ} \mathrm{C}$ for three months and they were found as potentially storable for keeping encapsulated bacterial cells alive. Overall, the results suggest that electrospun nanofibrous webs are suitable platforms for preservation of living bacterial cells and they can be used directly as a starting inoculum for bioremediation of water systems.
\end{abstract}

(c) 2017 Elsevier B.V. All rights reserved.

\section{Introduction}

There are different types of contaminants in wastewater effluents which are utilized in industrial processes, and dyes comprise a great portion in those industrial contaminants. Synthetic dyes have a great usage in various industries (e.g. textile, leather, paper) and dyeing process can lead to many environmental problems [1]. Methylene blue (MB) is a common basic, cationic dye with a broad application area in textile industry, paper industry, chemistry, biol-

Abbreviations: MB, methylene blue; PEO, polyethylene oxide; PVA, polyvinyl alcohol.

* Corresponding author at: Institute of Materials Science \& Nanotechnology, Bilkent University, Institute of Materials Science \& Nanotechnology, Bilkent, 06800, Ankara, Turkey. Tel.: +90 312290 8987; fax: +90 3122664365.

** Corresponding author at: Life Sciences Application and Research Center, Gazi University, 06830, Golbasi, Ankara, Turkey.

E-mail addresses: ttekinay@gazi.edu.tr (T. Tekinay), uyar@unam.bilkent.edu.tr (T. Uyar). ogy and medicine [1,2-7]. Nevertheless, decontamination of MB from water systems after use is still a major challenge. Conventional wastewater treatment methods can be used for remediation of MB such as photocatalysis [8], advanced oxidation processes [9], reverse osmosis [10] and electrochemical treatment [11]. Some of these techniques can be used efficiently for MB remediation, though each of them has their own limitations, hence innovative approaches have been presented in the literature for development of sustainable, environmentally friendly, cost-effective and efficient treatment methods [1]. Bioremediation is an alternative technology for decontamination of water systems by use of specific microorganisms, and it can provide green, efficient, cost-effective and sustainable remediation of water contaminants [12]. Microalgae, fungi and bacteria can be utilized for bioremediation. These microorganisms can remediate water pollutants either by biosorption or bioaccumulation. Although dead cell biomasses can only be used for biosorption, living cells can possess both bioaccumulation and biosorption, hence higher efficiency for bioremediation could be achieved by living cells in some studies [12]. 
The genus Pseudomonas comprises Gram-negative, aerobic, rodshaped bacteria and has a broad metabolic diversity [13], having a potential to be used in bioremediation studies. A popular member of this genus, Pseudomonas aeruginosa has already been used effectively in bioremediation of organic contaminants [1,14-16], implying this species as a potential candidate for further bioremediation studies.

Application of microorganisms for use in bioremediation can be performed with either free microorganisms or microorganism immobilized bio-hybrid materials. Immobilized microorganisms can bring advantages than free cells in terms of their potential reusability, lower space and growth medium necessities, and higher resistance to environmental extremes [17,18]. Electrospun fibrous webs have become a popular carrier matrix for immobilization of specific microorganisms for bioremediation of water systems [11,19-22]. Electrospinning can allow simple, versatile and cost-effective production of fibrous webs with unique properties such as high surface area and porosity, making electrospun fibrous webs as promising candidates for microbial integration and membrane/filter applications [23]. In recent years, a number of studies have been reported about encapsulation of microorganisms into electrospun fibrous matrices [23-27]. While viability or bioactivity of encapsulated microorganisms has been checked in all of these studies, just only very few of them have reported environmental applications [26-29].

In the present study, bioremediating bacterial cells were successfully encapsulated into polyvinyl alcohol (PVA) and polyethylene oxide (PEO) polymeric matrices while keeping the bacteria bioactive and the viable cell numbers in desirable amounts. Two water based and biocompatible polymeric matrices were selected for encapsulation of bacterial cells to reduce the effects of exterior environment on the viable bacterial numbers. These newly produced bacteria encapsulated nanofibrous webs were tested for their removal capacities against MB dye. It was found that, bacteria encapsulated webs have the potential to successfully remediate $\mathrm{MB}$ in water. In addition, the storability of bacteria encapsulated nanofibrous webs was tested in terms of the viable bacterial numbers. The results have shown that the encapsulated bacteria can be stored safely for long time periods without significant losses in their cell viability. These types of bio-hybrid materials could be of interest due to easy and safe preservation of bioremediating bacteria for potential wastewater treatment applications.

\section{Experimental}

\subsection{Materials}

The chemicals and reagents (polyvinyl alcohol (PVA, Mw $\sim 125.000$, Scientific Polymer Products, Inc.), polyethylene oxide (PEO, Mw $\sim 900.000$, Sigma-Aldrich), methylene blue (MB, $\geq 82 \%$, Sigma-Aldrich), Nutrient broth (Sigma-Aldrich), LB (Luria-Bertani) broth (Sigma-Aldrich) and Agar (Sigma-Aldrich)) were purchased and used without any purification. The deionized water was obtained from a Millipore Milli-Q Ultrapure Water System. All the chemicals were of high purity available and were of analytical grade.

\subsection{Procurement of the bacterial strain}

The commercial bacterial strain utilized in this study (Pseudomonas aeruginosa ATCC 47085) was purchased from ATCC (American Type Culture Collection, USA). The bacterial culture was enriched in LB medium (Luria-Bertani: $10 \mathrm{~g} / \mathrm{L}$ tryptone, $5 \mathrm{~g} / \mathrm{L}$ yeast extract, $10 \mathrm{~g} / \mathrm{L} \mathrm{NaCl}$ in $1 \mathrm{~L}$ of distilled water) and stock cultures were prepared from the initial broth. The stock cultures were stored at
$4{ }^{\circ} \mathrm{C}$ for short periods and fresh cultures were prepared from those samples prior to the further use.

\subsection{Electrospinning of bacteria encapsulated PVA and PEO nanofibrous webs}

PVA and PEO nanofibers were produced by using a single solvent system (water), but with different polymer concentrations. While for PVA nanofibers, the polymer concentration was $7.5 \%(\mathrm{w} / \mathrm{v})$ in the electrospinning solution, it was 3.5\% (w/v) for PEO nanofibers. The materials used for preparation of electrospun nanofibers were all sterilized by autoclave, and the inside of the Plexiglas box where electrospinning was carried out was sterilized by UV-C light to avoid contamination. Before electrospinning process, $2 \mathrm{X}$ concentrations of polymer mixtures, which were twice as densed as the regular concentrations, were prepared and then equal amounts of either bacteria-free distilled water or bacteria containing distilled water were mixed with these mixtures to obtain 1 Xelectrospinning solutions. In order to encapsulate sufficient amounts of bacteria within polymer matrices, the required bacterial amount was determined by dry cell biomass ( $\sim 4 \mathrm{mg}$ of bacterial biomass per $\mathrm{mL}$ of electrospinning solution, corresponding to $\sim 10^{10} \mathrm{cfu} / \mathrm{mL}$ ). The electrospinning solutions were loaded in $1 \mathrm{~mL}$ syringe fitted with a metallic needle of $0.6 \mathrm{~mm}$ inner diameter and they were located horizontally on a syringe pump (model KDS-101, KD Scientific, USA). One of the electrodes of high-voltage power supply (Matsusada Precision, AU Series) was clamped to the metallic needle and the other one was clamped to the grounded aluminum collector which was covered with an aluminum foil to deposit the PVA and PEO electrospun nanofibers. The electrospinning parameters were applied as: feed rate of solutions $=1 \mathrm{~mL} / \mathrm{h}$, applied voltage $=10-15 \mathrm{kV}$, tip-to-collector distance $=10-12 \mathrm{~cm}$. The electrospinning apparatus was enclosed in a Plexiglas box and electrospinning was carried out at $24{ }^{\circ} \mathrm{C} \pm 1$ and $\sim 20 \%$ relative humidity. The collected bacteria encapsulated nanofibrous webs were stored in a refrigerator $\left(+4^{\circ} \mathrm{C}\right)$ for quick or longer-term use. Only in one experiment, the bacteria encapsulated nanofibrous webs were stored at room temperature as well. Bacteria-free (pristine) nanofibers were stored at room temperature.

\subsection{Viability and storage tests}

In order to evaluate whether bacterial cells were properly encapsulated within PVA and PEO nanofibers, the Pseudomonas aeruginosa ATCC 47085 cells were stained with fluorescent stains (LIVE/DEAD BacLightTM kit) before mixing with the $2 \mathrm{X}$ concentrations of polymer mixtures. After preparation of electrospinning solutions, PVA and PEO nanofibers were collected on glass slides to observe under a fluorescence microscope. Microscopic evaluation of LIVE/DEAD-stained bacterial cells was made by the general assessment: bright green fluorescence emitting cells correspond to living cells and bright red fluorescence emitting cells correspond to dead ones. Photographs were taken by using a Leica optical microscope (Leica, DMI 4000 B) which has an attached fluorescence unit.

In addition to fluorescence microscopy, the viability of Pseudomonas aeruginosa ATCC 47085 cells in either electrospinning solutions or encapsulated within nanofibrous webs was determined via viable cell counting (VCC) assay. To find the encapsulation efficiency, equivalent pieces of the nanofibrous material was weighed which contain the encapsulated bacterial cells. Distilled water was added to these pieces and they dissolved rapidly in water, serial 10-fold dilutions were made and then the bacterial solutions were spread on LB agar plates. After overnight incubation at $30^{\circ} \mathrm{C}$, the number of colony-forming units (CFU) was counted. All tests were made in triplicate. 
a

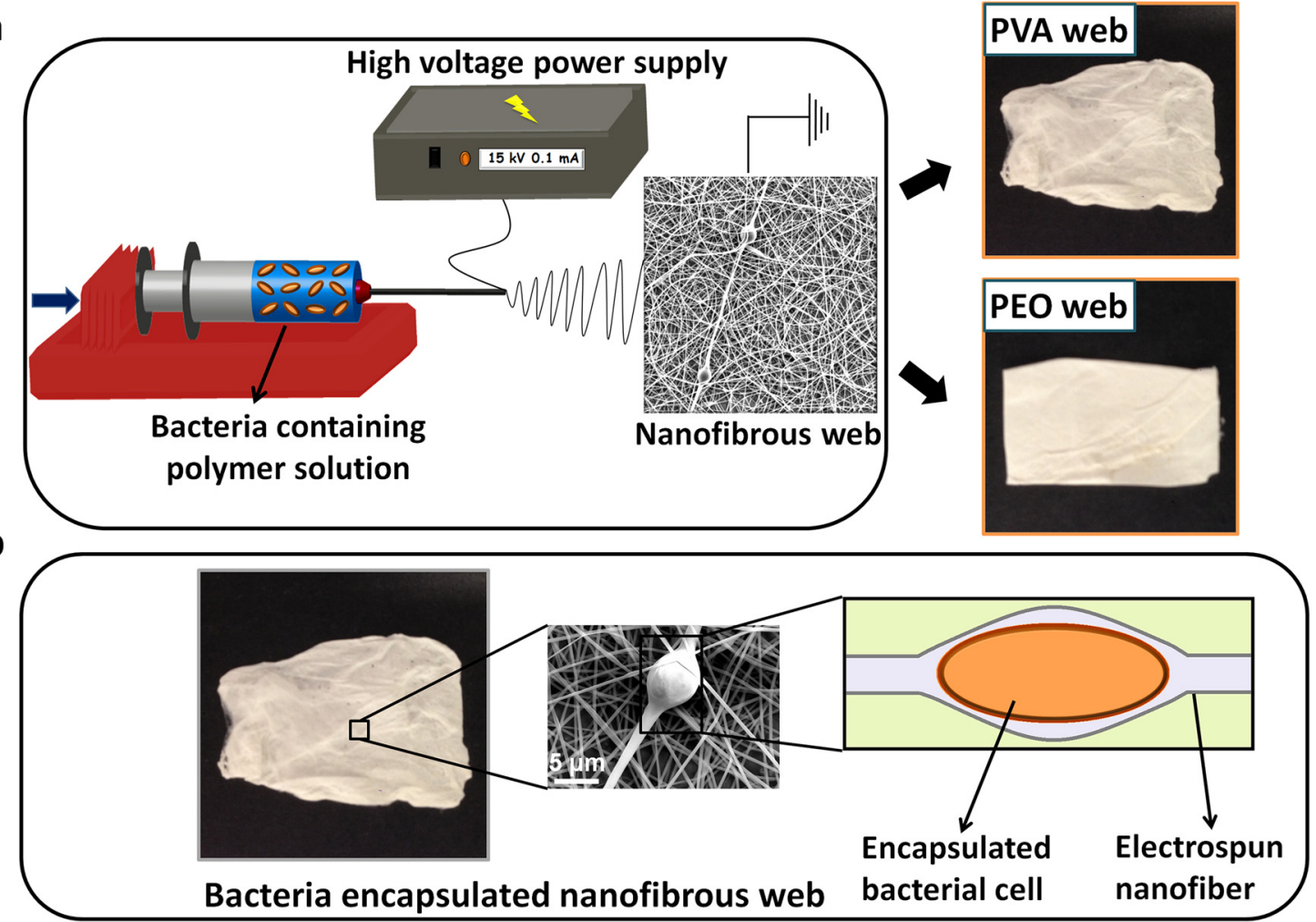

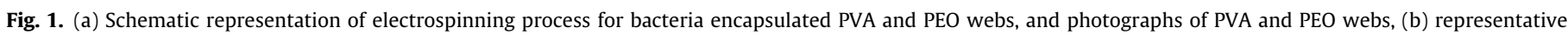
images for bacteria encapsulated webs including a SEM micrograph and a schematic representation of a bacterial cell inside PVA/PEO fibers.

For storage test, equivalent pieces were prepared for same samples and their viabilities were checked regularly for defined time periods. Bacteria encapsulated nanofibrous webs were tested for storability at $4{ }^{\circ} \mathrm{C}$ for 3 months and at $25^{\circ} \mathrm{C}$ for 10 days under dry conditions.

\subsection{Methylene blue (MB) bioremoval experiments}

LB broth was utilized as the bacterial growth medium for MB bioremoval experiments. The $\mathrm{pH}$ levels were constant and neutral (pH 7.0). Bacteria encapsulated PVA and PEO webs were added directly to MB containing LB broth for initiating bacterial growth. The effect of PVA and PEO in the growth media of dissolved webs on bacterial growth was evaluated by $\mathrm{OD}_{600}$ measurements. After achieving the bacterial cell viabilities of each bacteria encapsulated PVA and PEO webs in the range of $10^{7}-10^{8} \mathrm{cfu} / \mathrm{mL}$ per $10 \mathrm{mg}$, equivalent web samples (with $\mathrm{w} / \mathrm{v}$ ratio of $1 \mathrm{mg} / \mathrm{mL}$ ) were prepared for initiating MB bioremoval experiments. The initial bacterial cell viabilities of bacteria/PVA and bacteria/PEO webs were around $10^{7}-10^{8} \mathrm{cfu} / \mathrm{mL}$ and $10^{8} \mathrm{cfu} / \mathrm{mL}$ per $10 \mathrm{mg}$, respectively. Samples were collected periodically to analyze remaining MB concentrations by a spectrophotometer, and the specific absorbance of the dye was measured at $660 \mathrm{~nm}$. The samples were centrifuged prior to measurements for $5 \mathrm{~min}$ at $10,000 \mathrm{rpm}$, and the supernatant fractions were utilized for spectrophotometric measurements to avoid optical density interference from bacterial cells. Three different $(10,15,25 \mathrm{mg} / \mathrm{L})$ initial MB concentrations were tested for evaluation of the removal capabilities of bacteria/PVA and bacteria/PEO webs. The samples were incubated for $48 \mathrm{~h}$ at $125 \mathrm{rpm}$ and $30^{\circ} \mathrm{C}$. Free bacteria and bacteria-free web samples were tested for their MB removal capabilities as well, as positive and negative controls, respectively. The bacterial cell viabilities of initial inocula for free viable bacterial cells were adjusted around $10^{8} \mathrm{cfu} / \mathrm{mL}$ to compensate the initial cell viabilities of free and encapsulated bacteria. In order to evaluate the role of dead cells in MB removal, dead cells were also tested for MB removal at the same conditions. Bacterial cell viabilities were adjusted as $\sim 10^{10} \mathrm{cfu} / \mathrm{mL}$, corresponding to the total viable bacterial number within electrospinning solutions before starting the process, before killing bacterial cells at $70^{\circ} \mathrm{C}$ for $3 \mathrm{~h}$. All tests were done in triplicate.

The removal capacities $\left(\mathrm{Q}_{\mathrm{eq}}\right)$ of free bacteria cells, and bacteria encapsulated webs were calculated by Eq. (1):

$\mathrm{Q}_{\text {eq }}(\mathrm{mg} / \mathrm{g})=\left(\mathrm{C}_{0}---\mathrm{C}_{\mathrm{f}}\right) . \mathrm{V} / \mathrm{M}$

$\mathrm{C}_{0}$ is the initial MB concentration $(\mathrm{mg} / \mathrm{L}), \mathrm{C}_{\mathrm{f}}$ is the final MB concentration $(\mathrm{mg} / \mathrm{L}), \mathrm{V}$ is the solution volume $(\mathrm{L})$ and $\mathrm{M}$ is the total bacterial cell biomass $(\mathrm{g})$ at equilibrium [30].

\subsection{Scanning electron microscopy (SEM)}

Millimeter-length PVA and PEO webs were prepared for SEM analysis to evaluate morphologies of bacteria-free and bacteria encapsulated webs. Samples were coated with $5 \mathrm{~nm} \mathrm{Au-Pd}$ prior to SEM imaging (Quanta 200 FEG SEM, FEI Instruments, USA). The average fiber diameter (AFD) was determined from the SEM images, and around 100 fibers were analyzed.

\subsection{Reaction kinetics studies}

The order of reactions for MB removal process was evaluated upon the $\mathrm{R}^{2}$ values of zero, first, second and third order plots of free bacteria, bacteria/PVA and bacteria/PEO samples. 

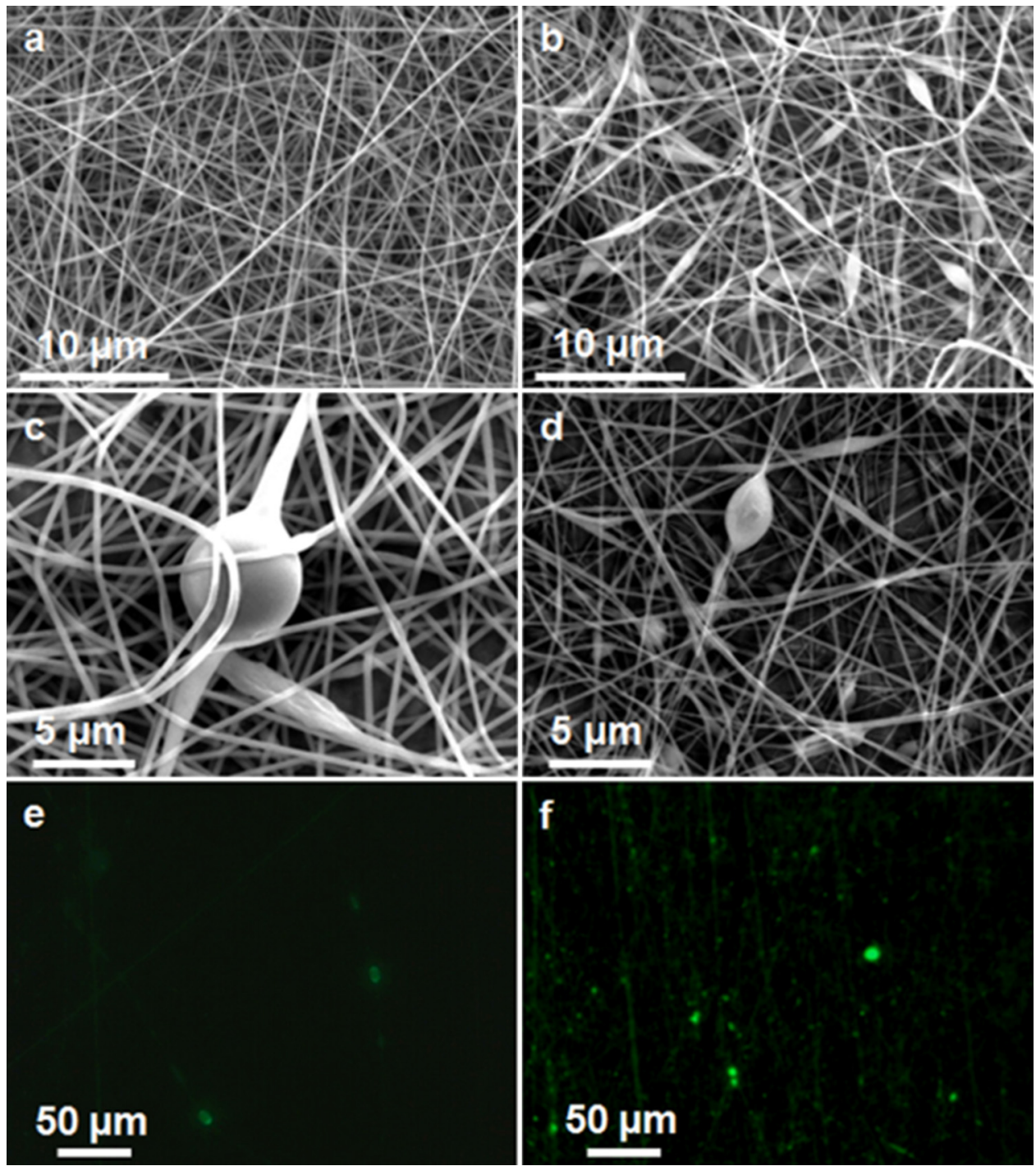

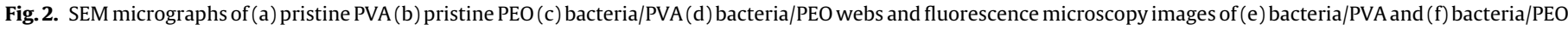
webs.

\section{Results and discussion}

\subsection{Encapsulation of bacteria within nanofibrous webs and} evaluation of bacterial cell viability

The electrospinning process for bacteria encapsulated nanofibrous webs is summarized in Fig. 1 schematically. Although the applied voltage for electrospinning process is highly detrimental for bacterial cells, it was needed to produce PVA and PEO nanofibers at these polymer concentrations. Therefore, in order to achieve the bacterial cell viabilities in desired amounts for the electrospun nanofibers, bacterial amounts in the electrospinning solutions were highly condensed, so that even after electrospinning and cell viability losses, there were sufficient amounts of viable bacteria within electrospun nanofibers. The encapsulation protocol is not a novel practice and there are several papers related with encapsulation of bacterial cells within electrospun fibrous webs for bioremediation [31-33]. As mentioned in these papers, the surviving cells can successfully preserve their removal capabilities and enzymatic activities against target contaminants. In addition, the experimental method used in this study was utilized after several optimization steps (the applied voltage was determined after optimization), which was the least harmful protocol for bacterial cells among dif- ferent experimental conditions. We agree that the process is still detrimental for bacteria, yet considerable (and sufficient for starting a new culture) amounts of living cells could be obtained after the process. Some additional preservation steps can also be utilized, for instance adding glycerol to the electrospinning solution to increase the bacterial cell viabilities during electrospinning process [34], yet since our study is a proof of concept study, we did not include them. Furthermore, use of biocompatible and biodegradable materials (e.g. polyvinyl alcohol, polyethylene oxide, alginate) for encapsulation can enhance the survivability of encapsulated cells during storage. The morphologies of bacteria-free and bacteria encapsulated electrospun PVA and PEO nanofibrous webs were evaluated by SEM imaging. The average diameters of pristine PVA and PEO nanofibers were measured as $420 \pm 35$ and $230 \pm 20 \mathrm{~nm}$, respectively. While bead-free nanofibers were obtained for pristine PVA nanofibrous web (Fig. 2a), beaded structures were obtained for pristine PEO nanofibrous web at $3.5 \%(\mathrm{w} / \mathrm{v})$ polymer concentration (Fig. 2b). It was found that bacterial cells were successfully encapsulated within PVA and PEO nanofibrous webs. Encapsulation of bacterial cells caused local widening of fibers in certain regions and ball-like structures were observed in these areas (Fig. 2c and d). In addition, it was noticed that the ball-like structures due to bacterial encapsulation are quite different (bigger and thicker) and 
Table 1

Removal capacities of free-bacteria, bacteria/PVA web and bacteria/PEO web samples at equilibrium at the end of the removal process. $\mathrm{T}=30^{\circ} \mathrm{C}$, agitation rate: $125 \mathrm{rpm}$, incubation time: $48 \mathrm{~h}(\mathrm{n}=3$, results show means \pm S.E.M $)$.

\begin{tabular}{lll}
\hline Sample name & Initial concentration $\left(\mathrm{C}_{0}\right)$ & $\mathrm{Q}_{\text {eq }}(\mathrm{mg} / \mathrm{g})$ \\
\hline Free-bacteria & $10 \mathrm{mg} / \mathrm{L}$ & $25.04 \pm 0.58$ \\
& $15 \mathrm{mg} / \mathrm{L}$ & $66.75 \pm 6.59$ \\
& $25 \mathrm{mg} / \mathrm{L}$ & $74.02 \pm 8.61$ \\
Bacteria/PVA web & $10 \mathrm{mg} / \mathrm{L}$ & $27.79 \pm 3.18$ \\
& $15 \mathrm{mg} / \mathrm{L}$ & $45 \pm 1.38$ \\
Bacteria/PEO we & $25 \mathrm{mg} / \mathrm{L}$ & $89.22 \pm 1.17$ \\
& $10 \mathrm{mg} / \mathrm{L}$ & $23.57 \pm 3.24$ \\
& $15 \mathrm{mg} / \mathrm{L}$ & $60.04 \pm 1.46$ \\
& $25 \mathrm{mg} / \mathrm{L}$ & $89.47 \pm 3.94$ \\
\hline
\end{tabular}

can be easily differentiated from the ordinary beads of pristine PEO nanofibers (Fig. 2d). Fluorescence microscopy images have shown that, the cell viabilities were preserved for the encapsulated bacteria in the PVA and PEO nanofiber matrices (Fig. 2e and f).

The bacterial cell viabilities were also checked by applying VCC assay on equivalent samples of bacteria/PVA and bacteria/PEO webs. As mentioned previously, before using in MB removal experiments, the cell viabilities were determined for each $10 \mathrm{mg}$ of bacteria encapsulated webs as around $10^{7}-10^{8} \mathrm{cfu} / \mathrm{mL}$ for bacteria/PVA and $10^{8} \mathrm{cfu} / \mathrm{mL}$ for bacteria/PEO webs. Bacteria/PEO web samples had always higher cell viabilities, possibly due to the higher $\mathrm{w} / \mathrm{v}$ ratio of bacterial cell biomass after dehydration for bacteria/PEO webs. After ensuring that the web samples have sufficient amounts of viable bacterial cells, biodegradation experiments were initiated with equivalents of those web samples.

\subsection{MB dye removal capabilities of bacteria/PVA and bacteria/PEO webs}

Electrospun bacteria/PVA and bacteria/PEO webs are readily water-soluble biocomposites which could be handy carrier matrix for bacterial storage and can be alternative to lyophilized bacteria for environmental remediation approaches in water. The effect of PVA and PEO polymeric solutions on bacterial growth was evaluated and no apparent differences were found for bacteria which were grown in polymeric solutions (Fig. S1), hence these webs can be used safely for starting bacterial inocula. Here, MB removal capabilities of bacteria/PVA and bacteria/PEO webs were tested at three different initial MB concentrations $(10,15,25 \mathrm{mg} / \mathrm{L})$. While both webs have shown lower removal yields at $10 \mathrm{mg} / \mathrm{L}$ of initial MB ( $52.5 \%$ for bacteria/PVA web and $44.4 \%$ for bacteria/PEO web), their removal yields increased at $15 \mathrm{mg} / \mathrm{L}$ ( $57 \%$ for bacteria/PVA web and $76 \%$ for bacteria/PEO web) and $25 \mathrm{mg} / \mathrm{L}$ (68\% for bacteria/PVA web and $69 \%$ for bacteria/PEO web) of initial MB, suggesting the removal process is biological rather than adsorption based, and might be enhanced by genetic switching at a defined concentration range (Fig. 3a). Even though PVA and PEO nanofibrous webs were quickly dissolved in $\mathrm{MB}$ aqueous solution, a very negligible decrease was observed in MB concentration with the addition of pristine PVA and PEO nanofibers, implying the removal performances of bacteria/PVA and bacteria/PEO webs were primarily based on the bacterial existence (Fig. 3b). In addition, dead bacterial cells have shown a very negligible decrease in the initial MB concentration after $48 \mathrm{~h}$ incubation, suggesting MB dye was primarily remediated by viable bacterial cells (Fig. S2). Removal capacities $\left(\mathrm{Q}_{\mathrm{eq}}\right.$ ) of free-bacteria cells and bacteria encapsulated webs were calculated for each concentration and are presented in Table 1 . The $Q_{\text {eq }}$ values of free-bacteria, bacteria/PVA web and bacteria/PEO web samples are similar at $10 \mathrm{mg} / \mathrm{L}$. At $15 \mathrm{mg} / \mathrm{L}$ of initial MB concentration, freebacteria sample has a higher $Q_{e q}$ value than bacteria encapsulated webs, and bacteria/PEO web has a higher $Q_{e q}$ value than bacte-
ria/PVA web. At $25 \mathrm{mg} / \mathrm{L}$ of initial $\mathrm{MB}$ concentration, the $\mathrm{Q}_{\text {eq }}$ values of bacteria/PVA and bacteria/PEO webs are very close to each other and both of them are higher than the free-bacteria sample. Since bacteria/PEO web samples had higher amounts of viable bacteria for the initial inoculum, their removal performances were higher than that of bacteria/PVA web samples in general, suggesting the bacteria encapsulated web samples can be improved for more efficient MB removal by increasing the encapsulated bacterial cell viabilities. In addition, by using a more capable bacterial strain for MB removal, higher removal performances even in shorter time periods can be obtained, as presented previously $[1,35]$. Not a regular trend was observed when comparing the removal performances of free-bacterial cells and bacteria encapsulated web samples. While the highest $\mathrm{MB}$ removal was observed by free-bacterial cells at $15 \mathrm{mg} / \mathrm{L}$, the highest MB removal was observed by bacteria/PEO web sample at $25 \mathrm{mg} / \mathrm{L}$, and the highest $\mathrm{MB}$ removal was observed by bacteria/PVA web sample at $10 \mathrm{mg} / \mathrm{L}$. These results might be occurred due to the differences in encapsulation efficiency for different bacteria encapsulated web samples, leading differences in initial inocula and hence maximal growth of the bacterial cells. Since encapsulation efficiency can be influenced batch to batch due to slight environmental changes (e.g. humidity), some fluctuations in bacterial numbers were observed for equivalent samples.

\subsection{Evaluation of order of reactions}

The $\mathrm{R}^{2}$ values of different order plots for MB removal are listed in Table S1. While bacteria/PVA web has shown the highest correlation with the zero order model $\left(R^{2}=0.9797\right)$, free-bacteria and bacteria/PEO web samples have shown the highest correlation with the first order model ( $R^{2}$ values of 0.9912 and 0.943 , respectively). These results conform with the results from the literature, since enzyme-catalyzed reactions often fall under the zero order model [36] and first order reactions can fit to the enzyme-driven reactions for biological removal of water contaminants [21].

\subsection{Storability and applicability of bacteria encapsulated webs}

The bacteria encapsulated web samples were tested for storability at different time periods via VCC assay, in terms of cell viability preservation. Different levels of cell viabilities were achieved in two different experiments (at $4{ }^{\circ} \mathrm{C}$ and $25^{\circ} \mathrm{C}$ ) and bacteria/PVA web sample had higher initial cell viability than bacteria/PEO web sample for the storage test at $25^{\circ} \mathrm{C}$ (Fig. $4 \mathrm{~b}$ ), unlike from the previous experiments, probably due to an influential batch to batch variation. Nevertheless, these differences did not have significant impacts on the assessment of storage test, since each sample has been evaluated individually and the comparisons were made on their initial to final cell viability ratios. In addition, although there are some variations in the cell viability measurements of bacteria encapsulated web samples for the storage test at $4{ }^{\circ} \mathrm{C}$, these are restricted in certain levels, hence it was supposed that the partial dissimilarities in the cell viability numbers for equivalent samples might be the reason for these variations. It was found that, while bacteria encapsulated web samples can be safely stored at $4{ }^{\circ} \mathrm{C}$ for months without significant losses in the initial cell viabilities, the cell viabilities rapidly decrease at $25^{\circ} \mathrm{C}$ and do not allow long-term storage at this temperature (Fig. 4, Table S2). Therefore, it was concluded that, the bacteria encapsulated web samples can be stored safely for long time periods, yet it needs cooler temperatures for cell viability preservation.

In brief, this study focuses on design and development of an alternative system with distinct features, rather than the removal efficiency for MB remediation. To the authors' knowledge, this is the first study which presents remediation of MB by bacteria encapsulated electrospun fibrous webs. The bacteria encapsulated webs 

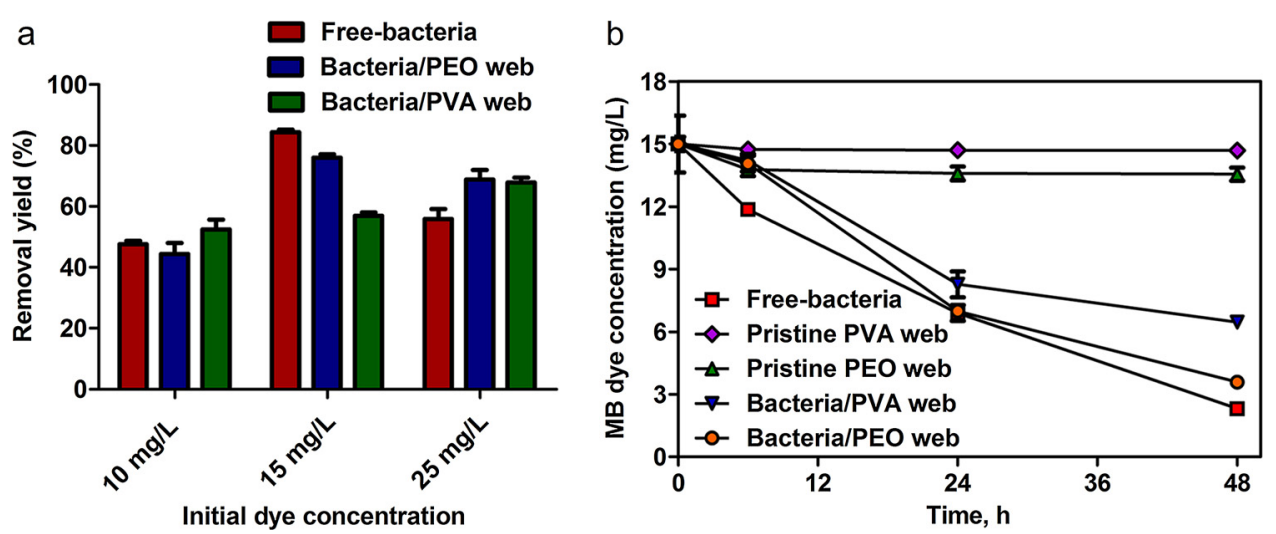

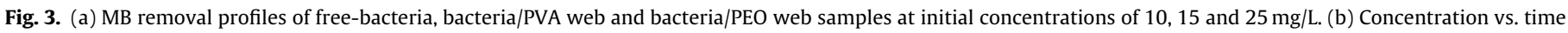
graph of free-bacteria, bacteria/PVA web, bacteria/PEO web, pristine PVA web and pristine PEO web samples at $15 \mathrm{mg} / \mathrm{L}$ of initial MB ( $\mathrm{n}=3$, graphs show means $\pm \mathrm{S} . \mathrm{E} . \mathrm{M})$.

a

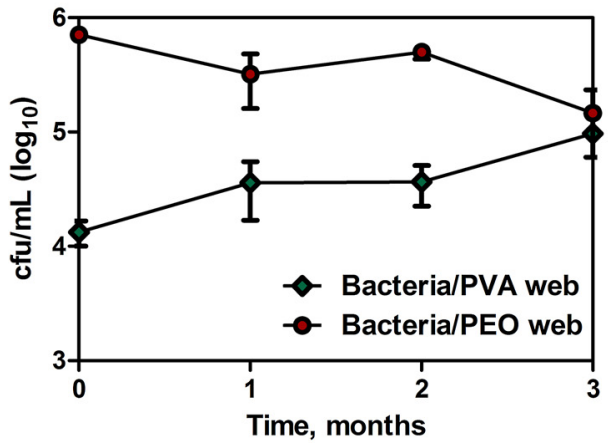

b

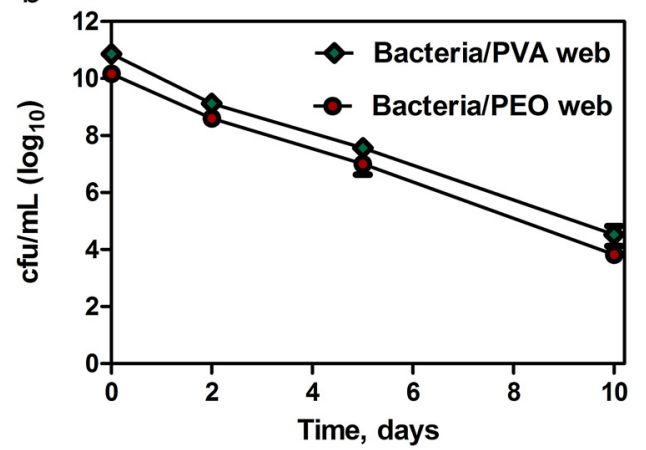

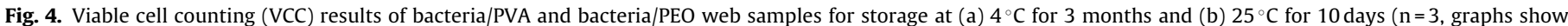
means \pm S.E.M).

have lower space and weight compare to free-bacteria in liquid media, which provides ease of application and lower transportation costs, as in lyophilized bacteria. In addition, these webs can be stored at cooler temperatures without significant losses in the cell viability. By optimization of environmental parameters and using a more capable bacterial strain in terms of removal efficiency against MB dye, more efficient biocomposites can be produced for remediation of MB. In this sense, the findings here are promising for further developments in this field.

\section{Conclusions}

In this study, we have developed functional biocomposite materials that were produced by encapsulation of a $\mathrm{MB}$ remediating Pseudomonas aeruginosa strain within electrospun PVA and PEO nanofibrous webs. The bacterial cell viabilities were checked by viable cell counting (VCC) assay and fluorescence microscopy imaging. Sufficient amounts of viable bacterial cells could be encapsulated within electrospun PVA and PEO nanofibrous webs, and these webs were tested for $\mathrm{MB}$ removal in water. The results of $\mathrm{MB}$ removal experiments revealed that $\mathrm{MB}$ removal capabilities of bacteria encapsulated webs were based on the bacterial presence, and similar removal performances were observed for free-bacteria. It was inferred that MB removal was achieved by biological removal rather than adsorption, and the removal performances can be optimized by increasing the initial cell viability numbers or using a more capable bacterial strain. In addition, storage test results showed that bacteria encapsulated webs can be stored safely for long time periods at $4{ }^{\circ} \mathrm{C}$, while preserving the initial cell viability numbers. This type of storage can be alternative to lyophilized bacteria and bring some advantages over storage in culture media; such as the web samples do not need any minimal growth medium and it requires very small spaces for storage. In conclusion, bacteria encapsulated electrospun nanofibrous webs can be effectively used for remediation of MB in water with storable and improvable properties.

\section{Acknowledgements}

The Scientific and Technological Research Council of Turkey (TUBITAK, project \#114Y264) is acknowledged for funding the research. Dr. Uyar acknowledges The Turkish Academy of Sciences - Outstanding Young Scientists Award Program (TUBA-GEBIP) for partial funding of the research. A. Celebioglu acknowledges TUBITAK project \#113Y348 for a postdoctoral fellowship. O.F. Sarioglu acknowledges TUBITAK BIDEB (2211-C) for National Ph.D. Scholarship.

\section{Appendix A. Supplementary data}

Supplementary data associated with this article can be found, in the online version, at http://dx.doi.org/10.1016/j.colsurfb.2017.01. 034.

\section{References}

[1] N.O. San, A. Celebioglu, Y. Tümtaş, T. Uyar, T. Tekinay, Reusable bacteria immobilized electrospun nanofibrous webs for decolorization of methylene blue dye in wastewater treatment, RSC Adv. 4 (2014) 32249-32255.

[2] N.S. Maurya, A.K. Mittal, P. Cornel, E. Rother, Biosorption of dyes using dead macro fungi: effect of dye structure: ionic strength and $\mathrm{pH}$, Bioresour. Technol. 97 (2006) 512-521. 
[3] A. Saeed, M. Iqbal, S.I. Zafar, Immobilization of Trichoderma viride for enhanced methylene blue biosorption: batch and column studies, J. Hazard. Mater. 168 (2009) 406-415.

[4] K. Vijayaraghavan, S.W. Won, J. Mao, Y.S. Yun, Chemical modification of Corynebacterium glutamicum to improve methylene blue biosorption, Chem. Eng. J. 145 (2008) 1-6.

[5] V.J.P. Vilar, C.M.S. Botelho, R.A.R. Boaventura, Methylene blue adsorption by algal biomass based materials: biosorbents characterization and process behavior, J. Hazard. Mater. 147 (2007) 120-132.

[6] X. Wang, X. Chen, K. Yoon, D. Fang, B.S. Hsiao, B. Chu, High flux filtration medium based on nanofibrous substrate with hydrophilic nanocomposite coating, Environ. Sci. Technol. 39 (2005) 7684-7691.

[7] N. Zaghbani, A. Hafiane, M. Dhahbi, Separation of methylene blue from aqueous solution by micellar enhanced ultrafiltration, Sep. Purif. Technol. 55 (2007) 117-124.

[8] R. Wang, J. Guo, D. Chen, Y.E. Miao, J. Pan, W.W. Tjiu, T. Liu, Tube brush like $\mathrm{ZnO} / \mathrm{SiO}_{2}$ hybrid to construct a flexible membrane with enhanced photocatalytic properties and recycling ability, J. Mater. Chem. 21 (2011) 19375-19380.

[9] Y. Zhan, H. Li, Y. Chen, Copper hydroxyphosphate as catalyst for the wet hydrogen peroxide oxidation of azo dyes, J. Hazard. Mater. 180 (2010) 481-485.

[10] S.K. Nataraj, K.M. Hosamani, T.M. Aminabhavi, Distillery wastewater treatment by the membrane-based nanofiltration and reverse osmosis processes, Water Res. 40 (2006) 2349-2356

[11] E. Rosales, M. Pazos, M.A. Sanromán, Comparative efficiencies of the decolourisation of leather dyes by enzymatic and electrochemical treatments, Desalination 278 (2011) 312-317.

[12] A. Malik, Metal bioremediation through growing cells, Environ. Int. 30 (2004) 261-278.

[13] M.T. Madigan, J.M. Martinko, Brock Biology of Microorganisms, eleventh ed., Prentice Hall, New Jersey, 2006.

[14] A.K. Karamalidis, A.C. Evangelou, E. Karabika, A.I. Koukkou, C. Drainas, E.A. Voudrias, Laboratory scale bioremediation of petroleum-contaminated soil by indigenous microorganisms and added Pseudomonas aeruginosa strain Spet, Bioresour. Technol. 101 (2010) 6545-6552.

[15] Y. Wang, J. Song, W. Zhao, X. He, J. Chen, M. Xiao, In situ degradation of phenol and promotion of plant growth in contaminated environments by a single Pseudomonas aeruginosa strain. J. Hazard. Mater. 192 (2011) 354-360.

[16] R. Pasumarthi, S. Chandrasekaran, S. Mutnuri, Biodegradation of crude oil by Pseudomonas aeruginosa and Escherichia fergusonii isolated from the Goan coast, Mar. Pollut. Bull. 76 (2013) 276-282.

[17] E. Eroglu, V. Agarwal, M. Bradshaw, X. Chen, S.M. Smith, C.L. Raston, K.S. Iyera, Nitrate removal from liquid effluents using microalgae immobilized on chitosan nanofiber mats, Green Chem. 14 (2012) 2682-2685.

[18] L. Hall-Stoodley, J.W. Costerton, P. Stoodley, Bacterial biofilms: from the Natural environment to infectious diseases, Nat. Rev. Microbiol. 2 (2004) 95-108.
[19] O.F. Sarioglu, O. Yasa, A. Celebioglu, T. Uyar, T. Tekinay, Efficient ammonium removal from aquatic environments by Acinetobacter calcoaceticus STB1 immobilized on an electrospun cellulose acetate nanofibrous web, Green Chem. 15 (2013) 2566-2572.

[20] N.O. San-Keskin, A. Celebioglu, T. Uyar, T. Tekinay, Microalgae immobilized by nanofibrous web for removal of reactive dyes from wastewater, Ind. Eng. Chem. Res. 54 (2015) 5802-5809.

[21] N.O. San-Keskin, A. Celebioglu, O.F. Sarioglu, A.D. Ozkan, T. Uyar, T. Tekinay, Removal of a reactive dye and hexavalent chromium by a reusable bacteria attached electrospun nanofibrous web, RSC Adv. 5 (2015) 86867-86874.

[22] O.F. Sarioglu, A. Celebioglu, T. Tekinay, T. Uyar, Evaluation of contact time and fiber morphology on bacterial immobilization for development of novel surfactant degrading nanofibrous webs, RSC Adv. 5 (2015) 102750-102758.

[23] W. Salalha, J. Kuhn, Y. Dror, E. Zussman, Encapsulation of bacteria and viruses in electrospun nanofibres, Nanotechnology 17 (2006) 4675-4681.

[24] W.Y. Fung, K.H. Yuen, M.T. Liong, Agrowaste-based nanofibers as a probiotic encapsulant: fabrication and characterization, J. Agric. Food Chem. 59 (2011) 8140-8147.

[25] Y. Liu, M.H. Rafailovich, R. Malal, D. Cohn, D. Chidambaram, Engineering of bio-hybrid materials by electrospinning polymer-microbe fibers, Proc. Natl. Acad. Sci. U. S. A. 106 (2009) 14201-14206.

[26] S. Klein, R. Avrahami, E. Zussman, M. Beliavski, S. Tarre, M. Green, Encapsulation of Pseudomonas sp: ADP cells in electrospun microtubes for atrazine bioremediation, J. Ind. Microbiol. Biotechnol. 39 (2012) 1605-1613.

[27] H.W. Tong, B.R. Mutlu, L.P. Wackett, A. Aksan, Manufacturing of bioreactive nanofibers for bioremediation, Biotechnol. Bioeng. 111 (2014) 1483-1493.

[28] N. Jiang, G.L. Ying, S.Y. Liu, L. Shen, J. Hu, L.J. Dai, X.Y. Yang, G. Tian, B.L. Su, Amino acid-based biohybrids for nano-shellization of individual desulfurizing bacteria, Chem. Commun. 50 (2014) 15407-15410.

[29] X.Y. Yang, G. Tian, N. Jiang, B.L. Su, Immobilization technology: a sustainable solution for biofuel cell design, Energy Environ. Sci. 5 (2012) 5540-5563.

[30] C.J. Buchko, L.C. Chen, Y. Shen, D.C. Martin, Processing and microstructural characterization of porous biocompatible protein polymer thin films, Polymer 40 (1999) 7397-7407.

[31] H.W. Tong, B.R. Mutlu, L.P. Wackett, A. Aksan, Silica/PVA biocatalytic nanofibers, Mater. Lett. 111 (2013) 234-237

[32] S. Klein, J. Kuhn, R. Avrahami, S. Tarre, M. Beliavski, M. Green, E. Zussman, Encapsulation of bacterial cells in electrospun microtubes, Biomacromolecules 10 (2009) 1751-1756.

[33] S. Klein, R. Avrahami, E. Zussman, M. Beliavski, S. Tarre, M. Green, Encapsulation of Pseudomonas sp. ADP cells in electrospun microtubes for atrazine bioremediation, J. Ind. Microbiol. Biotechnol. 39 (2012) 1605-1613.

[34] W. Salalha, J. Kuhn, Y. Dror, E. Zussman, Encapsulation of bacteria and viruses in electrospun nanofibres, Nanotechnology 17 (2006) 4675-4681.

[35] N.A. El-Sersy, Bioremediation of methylene blue by Bacillus thuringiensis 4 G1: application of statistical designs and surface plots for optimization, Biotechnology 6 (2007) 34-39.

[36] I. Tinoco, K. Sauer, J.C. Wang, Physical Chemistry - Principles and Applications in Biological Sciences, third ed., Prentice Hall, New Jersey, 1996. 